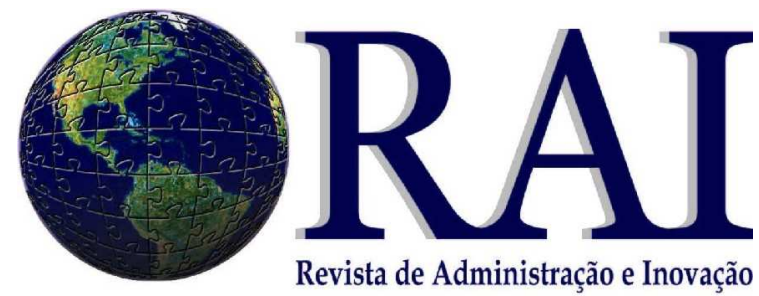

\title{
PUBLIC AND PRIVATE PARTNERSHIP PROJECTS RELATED TO URBANISM: LEARNING FROM A CASE STUDY
}

\author{
Thomas George Brashear Alejandro \\ Associate Professor Department of Marketing - Isenberg School of Management \\ University of Massachusetts Amherst \\ E-mail: brashear@mktg.umass.edu [USA]
}

\section{Claudia Rosa Acevedo}

Professora do Programa de Pós-Graduação em Administração - UNINOVE

Doutora em Administração de Empresa - EAESP/FGV

E-mail: claudiaraac@uol.com.br [Brasil]

\section{Jouliana Jordan Nohara}

Professora do Programa de Pós-Graduação em Administração - UNINOVE Doutora em Administração de Empresa - EAESP/FGV

E-mail: jnohara@uol.com.br [Brasil]

\begin{abstract}
The purpose of this paper is to describe a public and private partnership project related to revitalization of deteriorated urban areas. In this manner, this article presents a case study about the revitalisation of an old area in downtown São Paulo city, that is, the São Bento Square Area. The method of the investigation was based on the analysis of documents of the companies involved in the project and by in depth interviews with managers who have participated in the partnership. The data revealed that the partnership represents the turning point in the old downtown revitalisation project. In short, it emerges as a model to other proposals which has the same goal, not only in São Paulo, but also in other Brazilian cities that face the same problem in their old centers.
\end{abstract}

Keywords:. Public and private partnership; Project; revitalization proeject 
Public and private partnership projects related to urbanism: learning from a case study

\section{INTRODUCTION}

The purpose of this paper is to describe a public and private partnership project related to revitalization of deteriorated urban areas. In this manner, this article presents a case study about the revitalisation of an old area in downtown São Paulo city, that is, the São Bento Square Area. The method of the investigation was based on the analysis of documents of the companies involved in the project and by in depth interviews with managers who have participated in the partnership.

São Paulo, a city with almost 13 million dwellers, has been founded in January 1554 by the priests José de Anchieta and Manoel da Nóbrega, two Jesuists who built a school and a church next to an indian settlement in an upland between two rivers. This would be the beginning of the city.

In 1920 São Paulo had only 580.000 inhabitants and in 1930, there were already 1 million. At that time the society aimed to build a downtown, thus the public and private sectors goal was to invest in the infrastructure of the center. At the beginning of the century downtown was the place most visited in the city. It was busy during night and day. Most of the coffee plantation owners used to stay in downtown while visiting São Paulo. On the other hand, downtown was a place where all social classes used to meet at and work. As a consequence, all the financial institutions headquarters were settled there.

At the end of the 50's the old downtown was not only a business center but also an intellectual meeting point. Nevertheless, the lack of planning and political negligence brought to the area many problems, such as traffic congestion, lack of security, of leisure options and parking lots. From 1975 to 1985, downtown experienced an evacuation process, with big companies moving to other parts of the city. At the end of the 80's the social crisis of the country becomes deeper and as consequence there has been the arrival of beggars and street kids who made downtown their home. Consequently, the old centre became a dirty place, with graffiti, drugs and street sellers everywhere.

At the present days the main problems of the Old City Centre are: environmental and landscape deterioration; difficulty to get there by car, circulation problems; shortage of parking lots; real estate obsolescence and insufficiency; lack of self and patrimonial security.

On the other hand, the old downtown is the area that has the best infra-structure of the hole city. There is a complete network of water, light and drain. Moreover, it is a very well served area with collective transportation, which consists of seven metro stations, two train stations and 228 bus routes. In addition, the area concentrates $44 \%$ of the volume of the city's offices; 44,7\% of the country's financial activity; 90 hotels; 42 theatres and a complete services network. The 4,4 square kilometres of the Old City center bring together 3 million people a day, of which 430.000 are there to work (11\% of the city's total employment) and 200.000 to live. However, this infra-structure, which has been the product of investment of almost four centuries, is not entirely used at night and weekends.

\section{DOWNTOWN REVITALISATION IMPORTANCE}

The usual argument in the defence of downtown revitalisation is that it is better to use the present infra-structure, that is not entirely used, instead of employing public resources usually scarce - to build infra-structure in new areas throughout the city. However, this is not

RAI - Revista de Administração e Inovação, São Paulo, v. 2, n. 1, p. 78-88, 2005. 
the only reason to revive the city centre. Other reasons, as important as the first, are the necessity to preserve the history and the culture detained by the old centre.

In the context of a global economy, the development and the strengthen of the Old Center make possible to São Paulo to join the World Cities. These kinds of cities will compete to hostel the main corporations, organisations, congresses, symposiums and fairs, claiming, as a result, for a strong infra-structure of telecommunication, airports, hotels, leisure and culture. The candidate for a World City has to be efficient and to offer quality of life to its dwellers. If the Old Centre is powerful and articulated, it will contribute to the competitiveness of the hole metropolitan area.

There are some other important reasons for the revitalisation of the Old Center. One of them is the rebirth of the economy of the micro and small local companies. Similarly, there is the necessity to give to the region conditions of habitation, in order to diminish the crime and vandalism, stimulated by the city center emptiness after working hours and during weekends. Another reason is the urgency to restore buildings that are rich in architecture, but deteriorated. Usually they are partially occupied and have no garage or central air conditioner, have old lifts and electric and hydraulic installations in bad conditions. Moreover, the shortage of garages encourages the companies to move to other parts of the city, because their executives and clients can not park their car.

\subsection{THE REVITALISATION PROGRAMS}

As a world trend nowadays, downtown revitalisation programs are rising in Brazil. With slightly differences in content and names these programs have been spreading throughout the country. Despite some differences all have two common aspects: the maxim "save the city center" and the partisanship between the public and private sectors.

The benefit that the private sector searches with the downtown revival is the conservation of their own investment, because as the Old Center is deteriorated, it pulls the building prices down. What is more, the companies are using the revitalisation as a marketing tool. Joining the rebirth of downtown shows to the public that the company is ethic and has a modern concern about the city. This prizes its image.

RAI - Revista de Administração e Inovação, São Paulo, v. 2, n. 1, p. 78-88, 2005. 
Public and private partnership projects related to urbanism: learning from a case study

\subsubsection{Actors in the Partnership}

In the U. S. A. the restoration of the Old City Centers started in the 60's. Cities like Chicago, Philadelphia, Pittsburgh and Boston launched downtown re-qualification programs. Inspired in the Boston program, it was born in São Paulo city in 1991, Viva o Centro (Hail the Center) Association. It is an agency without profit purposes and which was the result of the awareness of many companies (settled in downtown or linked to it) about their role in the urbanisation development. The Association mission is to develop São Paulo Old Central area in its cultural, functional, social, economical and urban aspects, in order to transform it in a large, strong and efficient metropolitan center, contributing to the economic and social balance of the city.

Because of Viva o Centro success, two years latter, Pro-downtown (São Paulo Centre Urban and Functional Re-qualification Program) - a governmental agency linked to the Habitation and Urban Development State Department - was born, created by a Municipal Decree. Pro-downtown, created to plan and revitalise São Paulo center, has its members picked up from the Planning, Culture, Transportation and Habitation Departments and from some Regional Administrations. Its members come also from CMTC (Collective Transportation Metropolitan Company), Anhembi (tourism state owned agency), Civil Metropolitan Guard, CET (Traffic Engineering Company), Serpax (Publicity Companies Association) and Viva o Centro Association.

Another organisation which works for the revitalisation of the center is Local Action Program. It has around 30 cores which work in different areas of downtown. The Local Action Program main goal is to give quality of life, welfare and security to everyone who lives, works in the old downtown or passes through it. It is through the Local Action Program that downtown communities participate in an organised way in the daily administration of the micro areas of the centre like streets and squares. With the support of Viva o Centro Association, the program stimulates the composition of cores which have strict local actions. Its members are dwellers, employees and small company owners from the micro central areas. These cores have an uniform shape and are ruled by a standard statute. Local Action Program collaborate with the public sector by checking its performance, giving suggestions and creating partnerships with the intention to give quick solutions for daily problems, allowing the community to have an efficient action in the area. This proceeding provides a better quality of life to everyone who works and lives in the area. The main supporters of Local

RAI - Revista de Administração e Inovação, São Paulo, v. 2, n. 1, p. 78-88, 2005. 
Action Program are: BM\&F (Mercantile \& Futures Exchange), Bovespa (São Paulo Stock Exchange) with the co-ordination of Viva o Centro Association.

The social issue of São Paulo Old Center is the main focus of Travessia Foundation Project, which began its activities on November 1995, in order to work with street kids. It has been created by São Paulo Banking Labour Union and has BankBoston and Vicunha Group (one of the biggest private Brazilian corporations) as partners. This project has a US\$ 650.000 yearly budget. Psychologists, sociologists and artists take part in it and work in groups at the Old Center. After making acquaintance and conquering the kids reliance they organise games and cultural and sportive activities. These professionals are able to help the kids even with juridical issues. The main goal is to send the children back to their families, or help them to find step families or, in case of the older children, to help them to be self sufficient. The interesting point in this program is that it has begun with an alliance between the bankers and the bank labour union, that is, between capital and work.

\subsection{THE PARTNERSHIP ITSELF}

With the purpose of preventing the decay of São Paulo Old Center and assure its urban development, some partnerships between public and private sectors have arisen. The most important was the restoration of São Bento Square Area, where São Bento Monastery is settled. It is one of the most important historic, religious and architectonic buildings in São Paulo.

São Bento revitalisation complied the cleaning of the building's facade (full of graffiti, dust and pollution) and its illumination; restoration of the Monastery and Square floor; restoration of an old panel in the area; re-urbanisation of the Square, its maintenance, security and social work with street kids.

Each of these agencies/companies plays its own role in the partnership. A list of them and their roles are as follows:

- Viva o Centro Association:

$\hat{\imath}$ Responsible for the co-ordination of the project

- Pro-downtown:

$\hat{y}$ Co-responsible for the project co-ordination

- São Paulo City Hall:

今 Supplied the workers to do the job;

RAI - Revista de Administração e Inovação, São Paulo, v. 2, n. 1, p. 78-88, 2005. 
Public and private partnership projects related to urbanism: learning from a case study

$\hat{\nu}$ Square recondition; building floor and square floor restoration

s Strengthen the patrolling by the Metropolitan Civil Guard

今 Installation of the equipment donated by Philips.

今 Institutional support through the municipal Law 10.923/90

-BankBoston:

今 Monastery and São Bento School facade restoration and technical cleaning

$\hat{\imath}$ Private patrolling and maintenance of São Bento Square

今 Recondition of the German Walcker organ

今 Supporter of Travessia Project

- Philips Lightning/ Philips do Brasil:

今 Special illumination system for the Monastery and São Bento Church

- Akzo/Tintas Ypiranga:

$\hat{\imath}$ Donation of the paint for the restoration of an artistic panel

-J. P. Morgan:

$\hat{\imath}$ Interior illumination of São Bento Church

-Pires Vigilance:

$\hat{\imath}$ Ceded a guard to patrol the Monastery area

-São Bento Square Local Action Program:

$\hat{\imath}$ Responsible for the inauguration of a new police station connected to a closed TV system

$\hat{\imath}$ Daily supervision and maintenance of the micro-area

-Travessia Foundation Project:

今 Daily social work with street kids

The cleaning process and facade restoration has been executed by General Restoration Company, hired by BankBoston because of its specialisation in reconstitution of historical buildings. In order not to affect the granite and mortar facade surface, it was used non toxic and biodegradable state-of-the-art chemical products. This process followed international standards concerning quality and security. The intention was to remove the thick layer of pollutants, graffiti, fungus and moss that covered the facade, and afterwards, to cover the entire building with a protective covering from new graffiti.

RAI - Revista de Administração e Inovação, São Paulo, v. 2, n. 1, p. 78-88, 2005. 
Philips Lightening produced and donated 17 projectors to illuminate the external area of the São Bento complex - white light to the church and gold light to the Monastery and school. The projectors are equipped with four 2.000 Watt lamps and five 400 Watt lamps, all made of metallic steam. Besides, there are 26 lamps of sodium steam. In addition, photoelectric cells allow the devices to turn on automatically depending on the darkness level.

The building and square floor recondition was done by São Paulo City Hall. The purpose was to prevent infiltration and mould and make possible to install the modern illumination devices. It was also made a floor in Braille and set up a sounding semaphore to help the disabled to cross the streets near São Bento Square. A ramp with anti-skid floor leading to the Monastery was also built and, telephones and mailing boxes were installed in the area. The City Hall is still responsible for paying the electricity monthly bills.

Three video cameras were set up and connected with the police station. All this

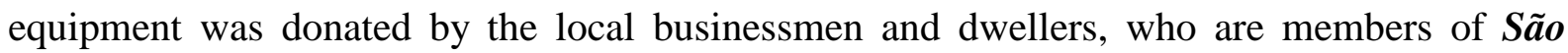
Bento Square Local Action Program. The duty of these people is also to supervise the maintenance of the area.

The total cost of the revitalisation of São Bento Square area, including the Monastery restoration, the external and internal illumination, was around US\$ 750.000. The project began on September 21 st, 1994 and will be concluded on March 1998, in time for the commemoration of the 400 years of the Monastery foundation.

The juridical instrument that rules the partisanship is the Term of Co-operation. It was signed on September $21^{\text {st }} 1994$ by the Mayor of the city, by the Urban Development and Habitation Department representative and by the private sector, represented by the president of Viva o Centro Association. Also signed the document the representative of São Bento Monastery. The main objective of the Co-operation Term was to settle terms of the competence of the agencies/companies in the partnership.

The partnership between the public and private sectors was possible because of Law 10.923/90, which decreases some taxes due by companies that invest in cultural projects.

\section{HISTORIC IMPORTANCE OF SÃO BENTO MONASTERY}

The São Bento Monastery was founded in 1598 by Benedictine priests and built at the same place where there was previously an Indian settlement. The first church was built in 1610 and, between 1762 and 1772 it was restored for the first time. At that time the Monastery

RAI - Revista de Administração e Inovação, São Paulo, v. 2, n. 1, p. 78-88, 2005. 
Public and private partnership projects related to urbanism: learning from a case study

Library was founded. In 1910 the old church was demolished and the construction of the current one had been started. The project, designed by the German architect Richard Berndt, assembles Romantic, Byzantine and Neo-Gothic details with Italian-influenced design. The total area of the current Monastery assemblage, comprised the church, the cloister and the school, sums an area of $18.000 \mathrm{~m}^{2}$. Today the cloister is inhabited by 40 Benedictine monks.

Nowadays the Monastery is not only a religious place, but also an artistic and cultural space. It has Brazil's best acoustic to receive orchestras. The church lodges a German Walcker organ from the XVIII century with 7.000 tubes. It is the biggest and the best organ in Brazil. Beyond architectonic richness, the Monastery lodges many sacred art objects of huge value and wide heap of books and paintings. In addition, the Monastery tower displays the city's most traditional clock, which was manufactured in Munich and installed in 1921. Because of its importance, it is considered São Paulo’s Big Ben.

\section{CONCLUSION}

It is clear from the case that the private sector in Brazil is starting to be conscious of its important role concerning the social issues of the community, as in a modern society this role is not - and can not be - anymore played only by the public sector. It is a shy but not late awakening.

The maxim in the modern administration theory is, not only for the private sector but also for the public sector, the search for efficiency. However, these organisations have to have in mind that it is useless to be efficient only in their own business if they are inserted in an unproductive and inefficient city, which is seriously jeopardised, because of the lack of functionality, low quality of life, and precariousness of its services and equipment.

São Bento Square Area revitalisation program not only recovers an important historic and tourist place in São Paulo city, but also confirms São Bento Monastery as one of the most important places to host cultural events. Evidencing this, four international organ festivals took place at the church from the end of 1994 up to 1997.

In conclusion, the successful partnership in São Bento Square Area re-qualification project represents the turning point in the old downtown revitalisation. In short, it emerges as a model to other proposals which has the same goal, not only in São Paulo, but also in other Brazilian cities that face the same problem in their old centers.

\footnotetext{
RAI - Revista de Administração e Inovação, São Paulo, v. 2, n. 1, p. 78-88, 2005.
} 
All above considered, São Bento Square area revitalisation project is a successful example of fostering enterprises, as it stimulates new partnerships between public and private sectors which are engaged in old downtown revitalisation causes with not only patrimonial restoration purposes, but also with social, historical and cultural ones.

\section{REFERENCES}

AS novas fachadas do Mosteiro. Jornal da Tarde, São Paulo, out. 1994.

AXÉ paulista. Veja São Paulo, São Paulo, p. 33, jun. 1996.

BARRETO, J. Uma ONG para o Centro. URBS, São Paulo, n. 2, p. 12 out. 1997.

BISCARO, F. Centro de São Paulo, ame-o ou deixe-o. Gazeta Mercantil, São Paulo, 24 out. 1996. p. D1.

BORTOLETTO, A. Restauração mostra detalhes da fachada do Mosteiro São Bento. Diário do Comércio, São Paulo, 12 set. 1994.

Prefeitura e empresas começam a recuperar o Largo São Bento. Diário do Comércio, São Paulo, 22 set. 1994.

BRASIL. SÃO PAULO (Município). Lei n. 10.923, 30 de dezembro de 1990. Dispõe sobre incentivo fiscal para a realização de projetos culturais no âmbito do Município de São Paulo. Diário Oficial do Município de São Paulo, São Paulo, p. 509-511, 30 dez. 1990

BRASIL. SÃO PAULO (Município). Decreto n. 33.389, 14 de julho de 1993. Cria Programa de Requalificação Urbana e Funcional do Centro de São Paulo - PROCENTRO a ser implantado na Área Especial de Intervenção, que especifica, e dá outras providências. Lex: Legislação do Município de São Paulo, p. 228-235.

BRUNO. A. Um som ainda mais divino. URBS, São Paulo, n. 4, p. 59 jan. 1998.

BRUNO. E. S. História e Tradições da Cidade de São Paulo. Rio de Janeiro: José Olympio, 1953, v.1, 2, 3 .

CARMONA, R. Interview on September 19, 1998

CENTRO das atenções. Construção, São Paulo, p. 6, out. 1996.

COMEÇA a reforma no Mosteiro de São Bento. Folha de São Paulo, São Paulo, 24 set. 1994.

FOLGATO, M. Restauração revaloriza mosteiro de São Bento. O Estado de São Paulo, São Paulo, 31 jan. 1995.

FONTES, F. Lojas ainda sentem a decadência. Gazeta Mercantil, São Paulo, 17 jul. 1996. p. 9.

RAI - Revista de Administração e Inovação, São Paulo, v. 2, n. 1, p. 78-88, 2005. 
Public and private partnership projects related to urbanism: learning from a case study

GITSIO, F. Largo de São Bento está mais iluminado. O Estado de São Paulo, São Paulo, 8 fev. 1995. Seu Bairro Centro, p. Z12

Basílica de São Bento terá nova iluminação. O Estado de São Paulo, São Paulo, 13 fev. 1998. Cidades, p. C8.

GRANDES cidades investem para mudar vida do centro. Folha de São Paulo, São Paulo, 19 maio 1997. p. 3-4 e 3-5.

LARGO de São Bento vai ser limpo e restaurado. Diário Popular, São Paulo, 22 set. 1994.

MACEDO, L. Centro: destruir para preservar. Jornal da Tarde, São Paulo, 13 dez. 1994.

MAGALHÃES, L. Projetos para o centro da cidade. Gazeta Mercantil, São Paulo, 22 set. 1994.

. A beleza escondida atrás da sujeira. Gazeta Mercantil, São Paulo, 23 set. 1994.

MOSTEIRO de São Bento passa por reforma. Jornal da Tarde, São Paulo, 22 set. 1994.

MOSTEIRO de São Bento vai ser restaurado. Folha de São Paulo, São Paulo, 25 ago. 1994.

MOSTEIRO purificado. Veja São Paulo, São Paulo, fev. 1995.

MOSTEIRO ganha nova iluminação. Metrô News, São Paulo, 30 jan. 1995.

. Folha de São Paulo, São Paulo, 31 jan. 1995. p. 33

O ETERNO centro velho. Em Casa (BankBoston), São Paulo, p. 6-11, março 1997.

PACHECO, C. A. Quatro séculos de fé. Já, São Paulo, p. 20-23, ago. 1997.

PARCERIA vai recuperar Mosteiro. O Estado de São Paulo, São Paulo, 22 set. 1994.

PAULINA, I. Brilho na noite. Veja São Paulo, São Paulo, p. 22-23, jan. 1997.

PROCENTRO terá suas propostas executadas logo. Diário do Comércio, São Paulo, 19 out. 1994.

PROJETOS para recuperar a economia dos centros urbanos. Gazeta Mercantil, São Paulo, 17 jul. 1996. p. 6.

RECUPERAÇÃO da fachada histórica ao som do órgão. The Boston News, São Paulo, ago. 1994.

REGIS, R. Marketing Central. Inovação Empresarial, São Paulo, p. 4-8, maio 1997.

TAUNAY, A. E. História da Cidade de São Paulo. São Paulo: Melhoramentos, 1953.

TOLEDO, R. P. Belos e Maltratados. Veja São Paulo, São Paulo, p. 102-105, nov. 1996.

RAI - Revista de Administração e Inovação, São Paulo, v. 2, n. 1, p. 78-88, 2005. 
Claudia Rosa Acevedo, Jouliana Jordan Nohara e Thomas George Brashear Alejandro . São Paulo é aqui. Veja São Paulo, São Paulo, p. 112-117, nov. 1996.

UM festival como nunca se viu. Veja São Paulo, São Paulo, ago. 1994.

VASCONCELOS, S. Largo de São Bento. Diário do Comércio, São Paulo, 25 ago. 1997, Cidades \& Entidades. p. 20-21

VEJA o que o Programa Ação Local pode fazer pela sua rua. URBS, São Paulo, n. 5, p. 7 fev. 1998.

VENTURA, M. Região é a mais perigosa para pedestres. O Estado de São Paulo, São Paulo, 27 out. 1994. Seu Bairro - Centro.

Data do recebimento do artigo: 13/10/2004

Data do aceite de publicação: 09/12/2004

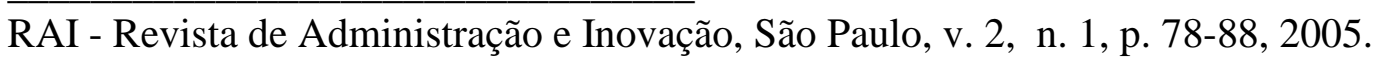

